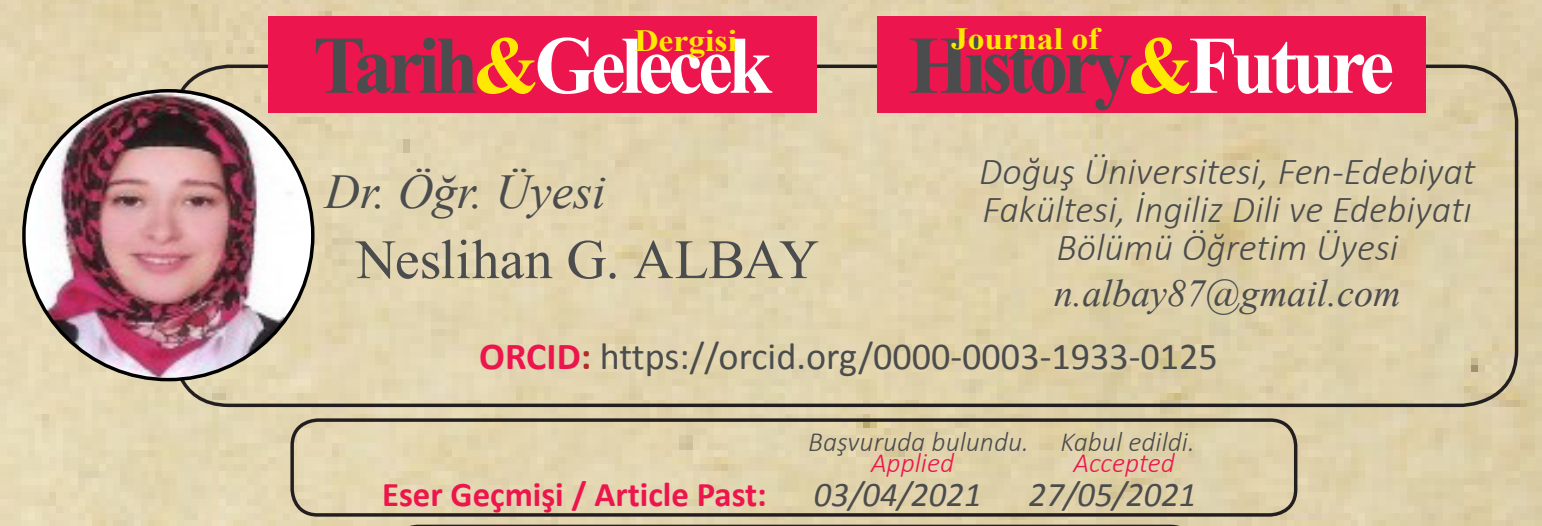

Araştırma Makalesi

DOI: http://dx.doi.org/10.21551/jhf.908870

Research Paper

Indexed by

ERIH JOLNALS

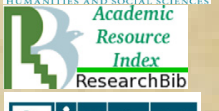

QISAM
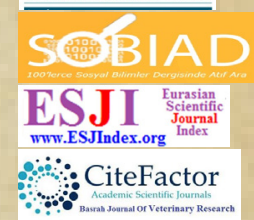

ideal

Orjinal Makale / Orginal Paper

\title{
Views of Ideal Society by Romantic Writers Against Social Injustice: Recasting the Revolution
}

Sosyal Adaletsizliğe Karşı Romantik Yazarlardan İdeal Toplum

Görüssleri: Devrimin Farklı Yorumu

\begin{abstract}
Social justice and equality are two concepts closely related to governmental systems, gender roles, and revolutionary acts realized for the sake of society. As long as these three elements serve to the needs or interests of the society, the welfare and happiness of that society can be maintained. The Romantic writers such as Thomas Paine, Edmund Burke and Mary Wollstonecraft discussed radical changes and revolutions from different perspectives and believed in their necessity for a more democratic and liberalist society, while Edmund Burke defends kingship and monarchical systems in which traditionality, and prejudices rather than change and discoveries are dominant. Trying to announce their populist, revolutionary or democratic ideas, some writers of the Romantic period also touch on significant cornerstones that guarantee the welfare of the society, such as democracy, women's rights, liberty, equality and justice. Therefore, the aim of this paper is to present different viewpoints by Thomas Paine, Edmund Burke and Mary Wollstonecraft over an ideal model of society particularly under the influence of the French Revolution. This paper will also discuss and illustrate the ways in which these writers of the Romantic period addressed problems of social injustice and inequality that have still prevailed in the modern world through nationalist sentiments. Thus, it also aims to demonstrate that revolutions and democratic systems outweighed monarchical systems in terms of social justice and equality as far as the welfare of the folk was concerned.
\end{abstract}

Key Words: Thomas Paine, Edmund Burke, Mary Wollstonecraft, nation, rights, freedom 


\section{$\ddot{\mathbf{O} z}$}

Sosyal adalet ve eşitlik, yönetim sistemleri, toplumsal cinsiyet rolleri ve toplum yararına gerçekleştirilen devrimci eylemlerle yakından ilgili iki kavramdır. $\mathrm{Bu}$ üç unsur toplumun ihtiyaçlarına veya çıkarlarına hizmet ettiği sürece, o toplumun refahı ve mutluluğu devam edebilir. Thomas Paine, Edmund Burke ve Mary Wollstonecraft gibi Romantik yazarlar, radikal değişimleri ve devrimleri farklı bakış açılarından tartışır ve genellikle daha demokratik ve liberalist bir toplumun gerekliliğine inanırken, Edmund Burke, değişim ve yeniliklerden ziyade gelenek ve önyargıların hakim olduğu krallık ve monarşik sistemleri savunur. Romantik dönemin bazı yazarları, popülist, devrimci veya demokratik fikirlerini açıklamaya çalışırken, demokrasi, kadın hakları, özgürlük, eşitlik ve adalet gibi toplumun refahını garanti altına alan önemli köşe taşlarına da değinmektedir. Bu nedenle, bu makalenin amacı, ideal bir toplum modeli üzerinden Thomas Paine, Edmund Burke ve Mary Wollstonecraft'ın farklı bakış açılarını sunmaktır. Bu makale aynı zamanda Romantik dönem yazarlarının modern dünyada hâlâ hüküm süren sosyal adaletsizlik ve eşitsizlik sorunlarını nasıl ele aldığını tartışacak ve örnekleyecektir. Dolayısıyla, halkın refahı söz konusu olduğunda, devrimler ve demokratik sistemlerin, sosyal adalet ve eşitlik açısından monarşik sistemlerden daha ağır bastığını vurgulayacaktır.

Anahtar Kelimeler: Thomas Paine, Edmund Burke, Mary Wollstonecraft, millet, haklar, özgürlük

\section{Introduction}

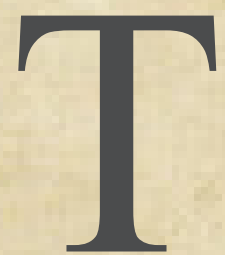

hroughout the centuries social injustice and inequality have been the reasons for many radical changes and revolutionary acts in varied societies. The violation of the rights of man has motivated the oppressed against the persecutors or dictators to gain more freedom and advantages for the sake of the providence and continuity of social order. The mouthpiece of the society in a way, some philosophers, thinkers or writers have taken these problems about social injustice and inequality as subjects to their works and made critical comments about them in their works. Being an inspiration for the abolition of slavery, collapse of feudalism and campaigns for universal suffrage, the French Revolution established the fundamental ideas and principles underlying Western liberal democracy with far-reaching results. Paving the way for the emergence of some significant values and institutions such as democracy, nationalism, liberalism, justice, equality, human rights and workers' rights, the French revolution seeded the idea of a more equal and egalitarian society with the consolidation of the national state. Along with the appearance of nationalist movements and the inauguration of the period of modern warfare, it caused the collapse of empires and monarchical governments and the establishment of nation-states. The revolutionaries of the Romantic Age believed in the revolution that they could, with their unlimited power, turn the society and the world into an "equal" and "free" place without war or disease.

Trying to announce their populist, revolutionary or democratic ideas, some writers of the Romantic period also touch on significant cornerstones that guarantee the welfare of the society, such as democracy, women's rights, liberty, equality and justice. With his work "Reflections on the Revolution in France" that has influenced all Europe and a great number of nations outside Europe since its publication year of 1790, Edmund Burke was commonly associated with an anti- 
revolutionary rhetoric. Recognized as an American political activist, writer, political theorist, and revolutionary, Thomas Paine influenced the American War of Independence and the French Revolution with his thoughts. The French Revolution had a profound effect on the life and literary career of Helen Maria Williams, who was a British poet, novelist and translator supporting radical causes. Likewise, playing a leading role in British feminism with a special emphasis on the education and status of the female sex and supporting the French revolution essentially, Mary Wollstonecraft desired equal education both for men and women with revolutionary ideas in her mind. Therefore, in my paper I will try to discuss different points of view by Thomas Paine, Edmund Burke and Mary Wollstonecraft over an ideal model of society as well as the French Revolution. This paper will also discuss and illustrate the ways in which writers of the Romantic period addressed problems of social injustice and inequality that have still prevailed in the modern world.

\section{Thomas Pain's Vision of Ideal Society}

The Rights of Man by Thomas Paine bears great importance since it compares and contrasts different governmental systems and tries to determine the status of the Nation within these systems. Thomas Paine criticized the monarchical and hereditary systems of the government since they put man into a wretched and impoverished position by imposing extreme taxes and so he regarded a revolution in the principles and construction of governments indispensable and inevitable because of these unjust political systems. For Paine, nobody can appropriate the government for the sake of their personal interests. It is the collective property of nation and it belongs to the Nation only. Besides, the Nation naturally has absolute rights to choose any form of government that it defends or to do away with the one it disagrees with. There is a relation of a part and a total between the sovereignty and the citizens of a nation. They are inseparable and complementary. When it becomes the property of an individual, there is an encroachment on the sovereignty of the nation. As Bush and Webb indicated, American independence was a significant milestone in the history of the world for Paine. In his introduction to Common Sense, Paine noted that "the cause of America is in great measure the cause of all mankind." It meant that he hoped "America would be the nation that would shine the new light of democracy out into the ancestral darkness of Europe, exposing and sweeping away the corrupt political and social institutions that for so long held the nations of the world in bondage." As regards the history of the American history Paine's eloquent speech instigated colonists and instilled the idea that they should manage to rule themselves rather than depending on Great Britain, particularly in his pamphlet Common Sense. This pamphlet played a pivotal role in proposing a democratic system that entailed the equal representation of each colony and favoured delegate voting for presidency. He emphasized the need to overthrow the abusive British rule in public eye and underscored that colonies should assume their new role of selfgovernors. In a way, his inflammatory speech in this work was a call for a complete break from British rule.

1 Thomas Paine, The Complete Writings of Thomas Paine. Ed. Philip S. Foner. New York: Citadel Press, 1969 , pp. 3-4

2 Harold K. Bush, JR \&Joe Webb, “Transfigured by Oratory: Thomas Paine, Robert Ingersoll, Mark Twain and the Roots of American Civil Religion. The Mark Twain Annual, No. 7, 2009, p.82. 
As far as government is concerned, it must have a comprehensive knowledge of all the objects and matters on which its authority dominates. In this respect, the republican system addresses to the whole nation. In this system it is the centre or the representative of all parts. However, in the old governments ruled by monks or kings, interests and happiness are excluded. Paine also compared the Revolutions of America and France to the ones that were formerly called Revolutions and he finds the first ones more radical and expansive than the second ineffective ones to a small extent. Related to the Revolutions of America and France he attracts our attention to their great impacts on different subjects, such as "a renovation of the natural order of things, a system of principles as universal as truth and the existence of man and combining moral with political happiness and national prosperity." As expressed by Len Travers in Celebrating the Fourth: Independence Day and Early Republic, Paine can be called as "one of the early republic's most prominent exponents of American civil religion. " Furthermore, according to Travers, as the voice of the Revolution, Paine considered "April 19, 1775 "the commencement of hostilities," to be a crucial moment when a new era for politics [was] struck," and "a new method of thinking" was initiated. ."

Drawing a general frame of different forms of governments and their distinctive qualities, Thomas Paine considered monarchical sovereignty as the enemy of mankind and the reason for misery and claimed the source and natural and original place of the sovereignty was the Nation. In no way can it be individualized. The political associations should serve only to public utility in the society whose members are "born and always continue, free and equal in respect of their rights." 6 To sum up, Paine was the defender of a nation-oriented system of government, and he objected to personal institutionalization in the structure of governments. In the "Life and Deeds of Thomas Paine," Ingersoll charged his audiences to remember that though "he has been pursued as [if] he had been a fiend from hell, Paine was one of America's great intellectual heroes - one of the men to whom [they] are indebted." Concisely, Paine's vision of America was very popular in the nineteenth century America, as well as Paine himself as a great hero, who did not give up his principles and remained faithful to his mission at the cost of death. Especially his pamphlet Common Sense had critical importance in changing American political thought permanently thanks to its eloquent and articulate arguments. It both activated American intellectuals to seek for independence and led to the drafting of the Declaration of Independence. Furthermore, it reflected the anti-British feelings of the Colonies elaboratively as Americans denounced the inherent fallacies of the monarchy and the English Constitution.

\section{Edmund Burke's Conservatism}

One of the ground-breaking events that led to profound impacts on the Western world in political history is unquestionably the democratic bourgeois revolution that occurred in France in 1798. There were two segments that either supported or opposed the idea of the French Revolution, and in this struggle that was launched for the sake of humanity, Edmund Burke had a biased and

3 Thomas Paine, The Rights of Man, ed. Eric Foner, Harmondsworth, 1984.

$4 \quad$ Len Travers, Celebrating the Fourth: Independence Day and Early Republic. Amherst: Univ.of Massachusetts, 1997, p. 22.

5 Travers, p.22.

6 Paine, The Rights of Man.

7 Robert G. Ingersoll, “Life and Deeds of Thomas Paine.” Robert G. Ingersoll's 44 Complete Lectures. Chicago: Regan Publishing, 1915, pp. 212-20. 
strict attitude towards the French revolution, since he supported the idea that rights and property are captured, and moral and religious values that strengthen social institutions are eradicated owing to revolution, in contrast to those thinking that revolution led to progress and enlightenment. The conservative thinker, Edmund Burke was convinced that the revolution would surrender to Jacobinism sooner or later because of its possible risks of failure based on its abstract ideas and its method containing violence and oppression. While "Thomas Paine stands out against Burke as a rival narrator of the revolution, and of the miseries of the people which Burke denied a place among the causes of the revolution ${ }^{8 "}$, in the Reflections on the Revolution in France, Edmund Burke supported the monarchical systems as a British statesman and political scientist. According to Paine, Burke favoured arbitrary / absolute power because he associated rights with responsibilities. Nevertheless, Burke never approved of absolute / arbitrary power and radical conservatism. Paine claimed that the revolution took place for the sake of these rights criticized by Burke, and the purpose of the revolution was to obtain these rights from the very beginning. ${ }^{9}$ One of the most prominent founding fathers of conservatism, Burke was a leading figure that made a criticism of the French Revolution at first. When almost all the peoples of the world, including Britain, approved of the revolution, Burke declared war on the Revolution because for him, revolution in general can be the last thing that should happen in a society, as revolution is harmful as a case that destroys the nature of society. He attempted to express intellectuals and politicians the inaccuracy of the radicalism of the revolution. He contrasted British traditional values with French innovations and suggested that radical ideas and new ways of thinking were not fit for the British, since the British were traditional. With a satirical view of the spirit of the French Revolution he opposed new ideas and rooted changes.

The thought of "grace" prevailed in Burke. Grace means God's wisdom, will or grace. The thought of grace includes the historically "supreme" and "inevitable" guidance of God and the "freedom of choice" of man. According to Burke, history has no laws. Even if these laws exist, only God's laws can exist. Burke did not see the French Revolution as a necessity; Revolution could be prevented if people did not want it, but its realization ultimately depended on God. As Tom Furniss noted in Edmund Burke's Aesthetic Ideology, "Burke seeks to immunize England by preventing the importation of radical ideas", which he fears will damage English political standards inherited from the Glorious Revolution. ${ }^{10}$ Burke's arguments were heavily rhetorical. He appealed to British patriotic sentiments to get support for his views. He proposed conservatism as an authentically British outlook in this way. He implied that most British people did not support the revolution because it is against British character and values of decency, nobleness, fairness, and hospitability. He reflected the British noble and the French as savage by giving a picture of warfare. He deduced that if the king and queen of France had been captured by them in the war, they would have been welcomed and honoured with a triumphal entry into London.

Burke thought that hierarchical society was natural. For him it was natural for one to feel admiration, respect and affection to one's special superiors. He expressed: "we look up with awe to kings; with affection to parliaments; with duty to magistrates; with reverence to priests; and with

8 David Bromwich, "Wollstonecraft as a Critic of Burke", Political Theory, Vol. 23, No. 4, 1995, p. 617. "

9 Thomas Paine, Ortak Akıl, Insan Hakları ve Tarımsal Adalet, çev. Faruk Gültekin, Doruk Yayınları, İstanbul, 2013, pp. 146-147.

10 TomFurniss, Edmund Burke's Aesthetic Ideology, Cambridge, 1993, p. 123. 
respect to nobility. Why? Because when such ideas are brought before our minds, it is natural to be so affected..." 11 This way of thinking is in stark contrast with the ideals of French Revolution. The defenders of French Revolution thought everyone was naturally equal and society made artificial hierarchy, while Burke believed hierarchy was natural. In his eye, if we do not respect our superiors, we will have false, wicked ideas and corrupted minds. He emphasizes their traditionality by saying: "we know we have made no discoveries, and we think that no discoveries are to be made, in morality, nor many, in the great principles of government, nor in the ideas of liberty." 12 This viewpoint seemed to be very shallow in contrast to Thomas Paine's. Edmund Burke believed in kingdom and monarchy, while Thomas Paine opposed them and supported more democratic governments and revolutionary movements. According to Burke, the Revolution is a struggle for power, not a fight for poverty, equality, freedom, fraternity; the compass or guide of the revolutionaries in this fight is "theoretical dogmas" and "philosophical speculation". According to him, other factors that prepared the Revolution were: Monarchy-nobility, the loss of the balance of the clergy-judges and the loss of authority of the crown. ${ }^{13}$ However, the point Burke emphasizes most in his critique of the Revolution was the rejection of religion, tradition, prejudices, and authority. Burke ruthlessly attacked the "philosophical fanatics" who rely on doctrines, philosophical speculation, who wage war on tradition, authority, religion, prejudices, because their aim was to abolish religion, the Church, and to create new citizens and a new society with a Jacobin attitude. ${ }^{14}$

Another radical revolutionist, Helen Maria Williams was English poet and novelist who was well-known for her support of radical causes. Her interests in social reform found expression in her Poem on the Slave Hill (1788) while her novel Julia (1790) referred to her opposition to slavery and support for the French Revolution. She was fascinated by the French Revolution and so she went to France alone to be a part of it. She was also abolitionist of slavery. However, she lamented the revolution when she saw the first victims of popular fury for the first time. She named those scenes of violence and ferocious revenge as a disgrace to the glories of the revolution. French Revolution symbolized the desire for liberty and overthrowing rigid hierarchical monarchist governments for her. She started to feel doubt about the revolution when she considered the violence associated with the revolution, since she normally had positive feelings because of its innovative features. She had not related it to death. Partly she had some despair but then she tried to understand the reasons why bloody murders or violence was committed. She both criticized and excused these aspects of French Revolution. We see that she supports the French Revolution for the sake of the liberty of many people if it should cost no further bloodshed. It is clear that this view was conducive to the development of social justice and equality.

As a criticism of French Revolution, Helen Maria Williams mentions Madame Roland in Letters Containing a Sketch of The Politics of France, who was executed as a victim of the Revolution. Madame Roland was one of the most successful women at that period and has "the

11 Edmund Burke, Reflections on the Revolution in France, London: Penguin Books, 1986.

12 Find

13 Michael Freeman, "Edmund Burke and the Theory of Revolution", Political Theory, Vol. 6, No. 3, August 1978. p. 282; Mihriban Şenses, Edmund Burke: Yüce, Etik ve Devrim, Yayına Hazırlanan Doktora Tezi, Uludağ Üniversitesi Sosyal Bilimler Enstitüsü, Bursa, 2018, p.138. 
most ardent attachment to liberty and the most enlarged sentiments of philanthropy. ${ }_{15}$ " However, she was imprisoned and sentenced to death. In spite of the bitter situation, she was exposed to, she was strong, brave and proud. The last words she said at the moment of being killed by looking at the statue of liberty near which the guillotine was placed is thought-provoking: "Ah Liberty, how you have been sported with!"'16 The scene is very ironical. The rights of living of the people who seek for liberty are cruelly taken from their hands during the Revolution. The aim of the Revolution was to give way for liberty, but the result is disappointing. Instead of people who were against the Revolution, people who supported and desired it were innocently executed. The aim of the Revolution seemed to have deviated from its right way. For this unfair condition Helen felt sorry and disappointed. This is the point she criticized about the revolution despite her gorgeous dreams of liberty. The French Revolution was the moment that occurred as a result of social injustice and inequality and aimed at gaining more extensive rights and for the interests of the folk. Therefore, Helen Williams defended the revolution despite its some extreme aspects and desired the establishment of social justice and equality as well as other writers of the Romantic period.

\section{Mary Wollstonecraft's Ideal Society}

The extension of women rights was another important balancing element in terms of social equality and justice. That they were undervalued and dominated by patriarchal societies were the central reasons for social injustice. As an early British revolutionary feminist thinker, Mary Wollstonecraft tried to reflect the qualities, attributed to women by the society and broadens our horizon about in which status women should in fact be in A Vindication of the Rights of Woman. In A Vindication of the Rights of Men (1790), which could also be considered as a precursor to Rights of Woman, Mary Wollstonecraft expressed her first plea for human freedom. Moreover, she targeted Edmund Burke's Reflections on the Revolution in France (1790), which is a text that "attempts to pre-empt political disease by pointing out the deleterious invasiveness of the democratic ideals fostered by the French Revolution. Burke commented on the "dreadful contagion" of the Revolution's "principles", a sentiment shared by a number of commentators during the pamphlet wars of the 1790s. ${ }^{17 "}$ "Although both writers differ in their perspective on the most desirable form of government, they resort to medical discourse in order to discuss the significant questions raised by the French Revolution about the nature and function of a healthy state as well as the role of the individual in preserving strong constitutions or removing diseased ones according to Amy Mallory-Kani. She asserts that the connection between politics and pathology established by Burke in his Reflections is also observed in Wollstonecraft's texts. She gives a comparison of these two writers more explicitly as follows:

Both writers make explicit connections among health, medicine, and politics. Their debate signals a concern for political health, a state that must be maintained by avoiding social diseases of various kinds. However, they differ specifically in their treatment of the means by which state health is fostered and sustained. While Burke views state health as possible only by barring the inoculation of foreign political ideas into the British political body, Wollstonecraft maintains that health must be nurtured from within the body politic; oppression should be corrected by internal

15 Helen Maria Williams, Letters Containing a Sketch of the Politics of France. 'Madame Roland'.

16 Ibid.

17 Amy Mallory-Kani, “A Healthy State”: Mary Wollstonecraft's Medico-Politics”, The Eighteenth Century, Vol. 56, No. 1, 2015, p. 21. 
reform..$^{18}$

The common point between two writers is their concern for political health that requires abstaining from every kind of social ills although they differ in their methods of maintaining state health. Burke's conservative nature opposed foreign political ideas within the British political body, while Wollstonecraft sook for internal solutions through internal reforms for the sake of political health. In a way, both took care of the essence of the state. However, as David Bromwich has observed, "the central feature of Wollstonecraft's response to Burke is not its defence of the French Revolution but its engagement with the moral position underlying Burke's political arguments-- a strategy unique to Wollstonecraft and one which necessarily broadens the intellectual context of this work well beyond the revolutionary pamphlet wars of the early $1790 \mathrm{~s} .{ }^{19^{\prime}}$ " The $18^{\text {th }}$ century British liberal feminist, Mary Wollstonecraft was the supporter of French Revolution and wrote to defend and justify it. She claimed that women's senses were stronger than their reason in social mind. She rejected the idea that women were inferior not because it is natural, but it was thought by the way society taught them. She made a plea for the betterment of women's status through radical reforms in national educational systems that would enable girls to have the same advantages as boys so that they could be successful in many professions besides being perfect wives and mothers.

In her feminist work In a Vindication of the Rights of Woman (1792), Wollstonecraft displayed her stance against the injustices inflicted on not only women but also men. She desired to be the mouthpiece of natural rights of humankind through her work with a particular emphasis on women's unequal position in society in a period of unrest, repression and reform. She discussed that the education system in her society-oriented women to be unskilled and frivolous intentionally and so she believed that a political change that requires a radical reform of the educational system would benefit the whole society. She thought women should not be confined intellectually or physically and believed man's superiority came from the inferior side of women. Gender inequality was defined socially, and education was the key factor in this kind of socialization. The education system of women made women dependent on men and not be able to rely on their own autonomous abilities. As referred by Gary Kelly in his article "Mary Wollstonecraft: Texts and Contexts", "Mary Wollstonecraft was versatile, and she was passionate, in a way which makes questions of her lack of 'masculine' logic and order, her lack of 'masculine' respect for facts and practicalities, merely academic. Her mind and imagination were unique. ${ }^{20}$ " Mary believed women were intellectually capable. What was problem was the prevailing opinion created by the society that women were created rather to feel than reason and their power lies in their charm and weakness. Since their understandings were neglected and their passions were pampered, they became the victims of their senses and this condition caused their abilities to become blunt. They were educated with novels, music, poetry, and gallantry so that they could become the creatures of sensation. Their feelings were tempted rather than their reason. In fact, women were naturally rational: it was a corrupt society that reflected their minds weak and their emotions strong. The judgement values of a society were very influential on determining gender roles in that society. Conceiving virtue as a means of self-discovery, Wollstonecraft elaborated:

19 Nancy Yousef, Wollstonecraft, Rousseau and the Revision of Romantic Subjectivity, Studies in Romanticism, Vol. 38, No. 4, 1999, p. 540. 
If virtue be an instinct, I renounce all hope of immortality; and with it all the sublime reveries and dignified sentiments that have smoothed the rugged path of life: it is all cheat, a lying vision; I have disquieted myself in vain; for in my eye all feelings are false and spurious, that do not rest on justice as their foundation, and are not concentred by universal love.

I reverence the rights of men. -- Sacred rights! for which I acquire a more profound respect, the more I look into my own mind; and, professing these heterodox opinions, still preserve my bowels; my heart is human, beats quick with human sympathies-and I FEAR God!21

Obviously, Wollstonecraft regarded Burke as an irreligious man identified with society. Because of social stereotypes, women were thought to be weak, dependent, and emotional in her time. However, they were naturally not, so Wollstonecraft desired women to reach the status they really deserved and to be regarded with aspects that were more dignified. The aim was not that they had power over men, but over themselves. That women were perceived as inferior and weak creatures did not match the rules of social justice and equality. Women should be given more rights rather than being forced to be dependent on men and being restricted unjustly. They should be allowed to act not with their repressed emotions, but their reason. Only in this way, can they discover their qualities and walk with sound steps in the society. Therefore, Mary Wollstonecraft challenged all stereotypes about women and defended unconventional ways against the traditional ways of thinking over women. In this sense, the vindication of the rights of women has a parallelism with social justice and equality. The domination of men and subjugation of women are the major obstacles to social order. Only when they disappear can social justice be executed." As Amy Mallory-Kani also emphasizes, "Wollstonecraft figures self-guided immunity as the ideal vehicle for political reform. In doing so, she reconfigures Burke's biomedical metaphors into literal aspects of socio-political regimen.22" She puts the responsibility on the individual within a nation for a solid political regimen and reforms by favouring social and gender equality. She wanted to be the voice of the injustices inflicted upon humankind and attempted to raise the awareness of both women and men of her period about them, while half the population was neither heard nor regarded as reasonable, intelligent human beings. She intended to draw the attention to social degradation that would be caused by the inequality of education between women and men as well as the restrictions imposed on human strength, value and productiveness.

\section{Conclusion}

The French Revolution undoubtedly led to radical changes in social order and universal consequences in world history because of its permanent effects on democracy, universal law and individual liberties. The critics of the revolution either appraised and favoured the revolution as precursor to progression or opposed it owing to its devastating effects on the social and political order such as the destruction of absolute kingdoms, moral and religious values. Thomas Paine regarded American independence as a milestone in the history of the world. He criticized the monarchical and hereditary systems of the government since they impoverished people owing to imposing extreme taxes and so he regarded a revolution in the principles and construction of governments indispensable. Paine was the defender of a nation-oriented system of government,

21 Janet Todd \& Marilyn Butler, The Works of Mary Wollstonecraft, 7 vols., London: Pickering,,1989, pp. 5:7-8. 
and he objected to personal institutionalization in the structure of governments. For Paine, nobody can appropriate the government for the sake of their personal interests. Edmund Burke proposed conservatism as an authentically British outlook and asserted that most British people did not support the revolution because it was against the British character and values of decency, nobleness, fairness, and hospitability. The Revolution is a move to overthrow the existing order completely and Burke foretold very early that such a move was doomed to result in a greater crisis or crises. He argued that institutions that lost their function in society should be reformed. Trying to preserve ancient traditions and institutions made Burke "conservative" and "anti-revolutionary", while his social analysis deemed the revolution as an unlikely and unacceptable phenomenon.

On the other hand, French Revolution symbolized the desire for liberty and overthrowing rigid hierarchical monarchist governments for Helen Maria Williams. She was concerned about the revolution only when she considered the violence associated with the revolution, since she normally had positive feelings because of its innovative features. She both criticized and excused the brutal aspects of the French Revolution. She supported the French Revolution for the sake of liberty and this view was conducive to the development of social justice and equality. Helen Maria Williams defended the revolution despite its some extreme aspects and desired the establishment of social justice and equality as well as other writers of the Romantic period. Having a great impact on the Romantic movement as well, Mary Wollstonecraft desired women to reach the status they really deserved and to be regarded with aspects that were more dignified, by opposing the mindset that placed women in subordinate positions. Her aim was not that women had power over men, but over themselves. She did not desire women to be independent of men as she was aware of the significance of marriage and the companionship of men. She was focused on a woman image centred on self, family and marriage. Her main concern was that many women were regarded to be unqualified in social life owing to improper education and to be devoid of reason. She put the responsibility on the individual within a nation for a solid political regimen and reforms by favouring social and gender equality. Her major wish was that women were addressed and treated as "human creatures" rather than females in the first place. Additionally, she proposed character, virtue and strength of mind as the principal features of a person of reason if a woman desires to be accepted and appreciated by society. As a feminist vanguard, she challenged all stereotypes about women and defended unconventional ways against the traditional ways of thinking over women. She lamented that women were not viewed in the same way as men. She asserts that only if more equality is established in society, morality will find the chance to gain ground. In this sense, the vindication of the rights of women had a parallelism with social justice and equality.

In conclusion, social justice and equality are two concepts closely related to governmental systems, gender roles, and revolutionary acts implemented for the sake of society. As long as these three elements serve to the needs or interests of the society, the welfare and happiness of that society can maintain. The Romantic writers such as Thomas Paine, Mary Wollstonecraft, and Helen Maria Williams discuss radical changes and revolutions from different perspectives and generally believe in their necessity for a more democratic and liberalist society, while Edmund Burke defends kingship and monarchical systems in which traditionality, and prejudices rather than change and discoveries are dominant. "A central concern for Burke and Wollstonecraft is the process by which states expel and/or exclude injurious elements from their systems. ${ }^{23 \text { " }}$ Burke envisions a form of immunity, or 
protection, that strives to thwart revolutionary infection by protecting the British body politic from external contagion. He advocates a sort of poultice, or surface remedy, which in Wollstonecraft's view, ultimately defies its intended effects by ignoring the body politics' internal infections. He offers us the method of protection of individuals and institutions formed by individuals for the future of humanity. The life and struggle of this conservative and liberal politician are the examples of how general concepts and institutions concerning his own country are preserved or they should be protected. A political and moral philosopher, Wollstonecraft argues that Burke's focus on external sources of political contagion (i.e., French principles), elides the internal problems that plague England. ${ }^{24 "}$ As his national cause is the cause of all mankind to a great extent, Pain considered making the world happy as a sacred responsibility within his authority. ${ }^{25}$ Thus, as far as the welfare of the folk was concerned, revolutions and democratic systems outweighed monarchical systems in terms of social justice and equality and they have still retained their significance and radicalism in modern societies with an influence that goes beyond their restricted time period.

\section{Bibliography:}

Bromwich, David. "Wollstonecraft as a Critic of Burke”, Political Theory, Vol. 23, No. 4, 1995, pp. 617-634.

Burke, Edmund. Reflections on the Revolution in France. London: Penguin Books, 1986.

Bush, Harold K., JR \& Webb, Joe. "Transfigured by Oratory: Thomas Paine, Robèrt Ingersoll, Mark Twain and the Roots of American Civil Religion. The Mark Twain Annual, 2009, No. 7, 2009, pp. 78-96

Freeman, Michael, "Edmund Burke and the Theory of Revolution", Political Theory, Vol. 6, No. 3, August 1978.

Furniss, Tom, Edmund Burke's Aesthetic Ideology, Cambridge, 1993.

Ingersoll, Robert G. "Life and Deeds of Thomas Paine." Robert G. Ingersoll's 44 Complete Lectures. Chicago: Regan Publishing, 1915.

Kelly, Gary. "Mary Wollstonecraft: Texts and Contexts," Eighteenth-Century Life. Vol. 2, 1975.

Mallory-Kani, Amy. “A Healthy State”: Mary Wollstonecraft's Medico-Politics”. The Eighteenth Century, Vol. 56, No. 1, 2015, pp. 21-40.

Paine, Thomas (2003). Common Sense, Rights of Man, and Other Essential Signet Classics. , Ortak Akul, Insan Hakları ve Tarımsal Adalet, çev. Faruk Gültekin, Doruk Yayınları, İstanbul, 2013.

, Rights of Man. ed. Eric Foner, Harmondsworth, 1984.

Press, $\overrightarrow{1969}$.

, The Complete Writings of Thomas Paine. Ed. Philip S. Foner. New York: Citadel

24 Ibid.

25 Paine, The Complete Writings of Thomas Paine, p. 121. 
Şenses, Mihriban. Edmund Burke: Yüce, Etik ve Devrim, Yayına Hazırlanan Doktora Tezi, Uludağ Üniversitesi Sosyal Bilimler Enstitüsü, Bursa, 2018.

Todd, Janet \& Butler, Marilyn. The Works of Mary Wollstonecraft, 7 vols. London: Pickering, 1989, 5:7-8.

Travers, Len. Celebrating the Fourth: Independence Day and Early Republic. Amherst: Univ. of Massachusetts, 1997.

Williams, Helen Maria. Letters Written in France in the Summer of 1790. 'On Revolution', Letters Containing a Sketch of the Politics of France. 'Madame Roland'.

Wollstonecraft, Mary. A Vindication of the Rights of Woman. Penguin Classics, 2004.

Yousef, Nancy. Wollstonecraft, Rousseau and the Revision of Romantic Subjectivity. Studies in Romanticism, Vol. 38, No. 4,1999, pp. 537- 557. 